\title{
Character Association in French Bean (Phaseolus vulgaris L.) and Pea (Pisum sativum L.) A Review
}

\author{
Akshita Bisht and Savita* \\ Lovely Professional University, Phagwara, Jalandhar (Punjab), India \\ *Corresponding author
}

\section{A B S T R A C T}

Keywords

French bean,

Genetic advance,

Genetic variability,

Heritability, Path

coefficient and Pea

Article Info

Accepted:

07 October 2020

Available Online:

10 November 2020
French bean and Pea are an important vegetable crop consumed by human being as green pods and dry seeds due to its high nutritive value as the source of the amino acid, lysine and tryptophan as well as provides valuable dietary protein in the human diet. Considering its use as a vegetable which fits well indifferent cropping systems, there is need for improvement and development of cultivars to specific agro ecological conditions. The knowledge of genetic diversity is an important tool for any breeding programme aimed to exploit hybrid vigour. Moreover, the information related to the nature and extent of association among various yield attributes, direct and indirect influence of each of the component traits on yield could prove helpful in formulating effective breeding strategy. The magnitude of the variability present in a crop species is of utmost importance for the relative improvement of the cultivars, suitable for a particular region. Thus, there is a need to develop varieties having good yield and quality characters. For this, the breeder requires a good knowledge of variability. The subsequent study of interrelations among different characters further helps in bringing effective improvement.

\section{Introduction}

Pea (Pisum sativum L.) is an important leguminous vegetable crop grown in many parts of the world i.e., temperate and subtropical regions, for fresh green immature pods. Sometimes it is utilized as a pulse crop and also as a green manure crop. It belongs to the family Leguminosae (Fabaceae) having chromosome number $2 \mathrm{n}=14$, with its origin Central Asia. Pea growing states are Uttar Pradesh, Haryana, Himachal Pradesh, Uttarakhand, Punjab, and Karnataka. However. Uttar Pradesh is the leading state of pea production in India sharing $46.1 \%$. Total area in India under pea cultivation is about 554-thousand-hectare area and the production is 5524 thousand MT having an annual productivity of 8.9 MT per hectare (NHB, 2018). Pea has a great nutritive value $\&$ contains vitamin $\mathrm{A}, \mathrm{B}$ and $\mathrm{C}$ along with minerals, dietary fiber \& antioxidant compounds (Urbano et al., 2003). In addition, it also has high nutritive value i.e. proteins $7.2 \mathrm{~g} / 100 \mathrm{~g}$, carbohydrate $14 \mathrm{~g} / 100$, dietary fiber $5 \mathrm{~g} / 100 \mathrm{~g}$. Peas are excellence source of protein, help in digestion, protective against some chronic diseases, prevent constipation and reduce bad cholesterol. 
French bean (Phaseolus vulgaris L.) is an important leguminous vegetable crop grown for its tender green beans and dry beans (Rajmah). It belongs to the family Leguminosae having chromosome number 22. It is known by many names i.e. common bean, haricot bean, marrow bean, bush bean, dry bean, string bean, kidney bean and field bean etc. It is grown in U.S.A., Latin America, Canada, India, Bangladesh, Nepal and almost in all European countries. In India it is cultivated in many states of Maharashtra, Jammu and Kashmir, Himachal Pradesh, Uttar Pradesh hills, Nilgiri (Tamil Nadu), etc. In addition, it is a nutritious vegetable containing $1.7 \%$ protein, $0.1 \%$ carbohydrate, $4.5 \%$ fat, $1.8 \%$ fibre and $0.5 \%$ mineral matter. The green pods are rich in calcium, potassium and iron.

Basically, India has very low production and productivity of Pea (Pisum sativum L.) and French bean (Phaseolus vulgaris L.) due to the lack of high yielding hybrid/varieties. Hence it is very important to develop high yielding varieties, hybrids of Pea and French bean having good protein content and resistance to biotic and abiotic stress, which can be released as such for commercial production or can be used in the crop improvement program for improvement of yield and quality traits. For increasing production and productivity, we should examine a genetic improvement factor and the finest and superior way is to study the genetic parameter \& character association in French bean and Pea. Considering the significance of above said facts the review paper entitled 'character association \& path analysis in various genotypes of French bean and Pea for pod yield \& quality traits' has been drafted with the following objectives. This paper mainly reviews genetic variability, heritability, genetic advance, correlation, path coefficient and genetic divergence in Pea and French bean $\&$ focuses on potential areas for further research and development of high yielding varieties and hybrids of Pea and French bean.

\section{Genetic variability}

It is defined as the presence of genetic differences in individuals differing in genotype. PCV include the genotypic variance with the environmental variance and their interaction. GCV is due to the genetic causes or the occurrence of differences among individuals due to differences in their genetic makeup. It is usually stable and is not influenced by any environmental factor. Many scientists studied about it and observed that for traits days to maturity and pod length maximum variability was recorded in 31 genotypes (Raffi et al., 2004). High variability for pod break length, pod total /plant \& yield potential characters and low genetic variability for time of flowering, time of harvest, pod weight, pod diameter, pod length, seed/pod and 100 seed weight were observed in three genotypes (Rachman et al., 2006). Highly significant differences in yield, leaf area, pod length \& width, pod number /plant, fresh pod weight, seed number /pod and 100 seed weight were recorded (Dursun, 2007). For days to maturity, 100-seed weight, protein content, seed yield per plant and days to $50 \%$ flowering maximum variability recorded in forty-five genotypes (Singh et al., 2007). Among 12 genotypes of Pea, significant differences in all germplasm for days to germination, days to $50 \%$ flowering, no. of pods per plant, weight of pods per plant, pod length, no. of seed per pod, 100 seed weight and green pod yield were observed (Nawab et al., 2008). While evaluating genetic variability in 32 genotypes significant differences were observed for all characters except no. of primary branches and grain yield per plant, no. of pods per plant, no. of seeds per pod and 100 grain weight showed high GCV and PCV (Kumar 2008). In 10 
indigenous and exotic genotypes of pea significant varietal differences for all characters were recorded. Highest GCV and PCV were exhibited by seeds per plant, shoot height, internodal length, pod yield and pod number (Guleria et al., 2009). Highest GCV and PCV were recorded for No. of pods per plant, seed yield per plant and 100 seed weight in field Pea crosses in F3 generation (Lavanya et al., 2010). Moderate to high level of GCV and PCV for days to 50\% flowering, plant height, no. of pods per plant, days to maturity, no. of seeds per pod, pod length, seed weight and grain yield per plant were recorded. Phenotypic variance for all characters was higher than genotypic variance (Jaiswal et al., 2013). Maximum variability in plant height, number of pods /plants, 100 seed weight \& seed yield were recorded for fiftyseven genotypes (Ahmed et al., 2013). High variability for marketable pod yield /plant, plant height, no. of pods/plants, no. of inflorescences /plant \& 100 seed weight was recorded for forty-four genotypes (Kumar et al., 2014). Maximum variability for plant height after 30 days of sowing, leaf length, leaf width, days to $50 \%$ flowering, pod length, pod width, number of marketable pod /plant, pod yield /plant, seed length, seed width, 100 seed weight $\&$ green pod yield was recorded in forty four genotypes (Savita et al., 2014). Highest variability for days to flowering, days to first picking, average pod weight, pod length, pods /plant, plant height $\&$ pod yield /plant was recorded in seventeen genotypes (Devi et al., 2014). In 12 genotypes of Pea significant analysis of variance was recorded except for plant height. Highest Genotypic coefficient of variation and Phenotypic coefficient of variation was recorded in pod/plant, seed yield/plant \& lowest in days to maturity (Ahmad et al., 2014). Among 54 Pea genotypes which includes 4 checks and were grown in RBD with 3 replications maximum variability were recorded in all genotypes for all morphological traits. Total soluble solids, total sugar, pod yield/ha and total phenols exhibited highest GCV \& PCV (Kumar et al., 2015). Significant variability in green pod yield /plant, plant height, germination percent \& protein was observed in twenty-five genotypes (Prakash et al., 2015). The seeds were treated with different concentration of chemical mutagen i.e., gamma ray's high variability was recorded for plant height, length of pod, days to maturity and number of pods per plant (More et al., 2016). Very high variability in plant height, seed yield /plant, pod yield /plant, pod yield /hectare, number of pods /clusters, no. of pods /plant \& 100 seed weight was recorded in seventy-four genotypes (Panchbhaiya et al., 2017). For seed weight /pod, plant height, pods /plant, no. of leaves /plants, pod weight \& pod yield/plant, maximum variability was found in eighteen different genotypes (Lyngdoh et al., 2017). In nine French bean (Phaseolus vulgaris L.) genotypes grown at two different locations highest variability for primary branches, grain yield, hundred seed weight \& number of pods /plants was recorded (Wondimu et al., 2017). In 15 genotypes of Pea, significant differences among all genotypes were observed regarding growth yield and yield attributes parameters. Moderate PCV and GCV were exhibited by plant height, no. of branches, no. of leaves, leaf area, days to initiation of first flowering, no. of clusters/plant, pod length, no. of seeds per green pod, green pod yield/plant, pod yield/plot, pod yield/hectare and crop duration (days) (Tambolkar et al., 2017). In 120 genotype of field Pea along with 4 check varieties, analysis of variance showed significant differences in all the genotypes for all traits except no. of primary branches per plant. All the genotypes showed moderate to high level of GCV and PCV. PCV were higher than GCV in magnitude (Lal et al., 2018). High variability in plant height, no. of primary branches, pod length, pod width, pod 
flesh thickness, no. of pods per cluster, no. of pods /plant, weight of ten pods, no. of root nodules /plant \& dry matter contents of pods $\&$ roots were recorded in thirty-six genotypes (Jhanavi et al., 2018). Maximum variability was observed for no. of branches/plant, pod yield/plant \& pod yield per plot (Vijayakumar et al., 2019). While estimating genetic variability in quantitative characters in new varieties of field pea using one line \& their $\mathrm{F}_{3}$ $\& \mathrm{~F}_{4}$ hybrids, significant differences were recorded for number of pods/plant, number of grains/pod, 1000 seed weight \& grain yield (Lakić et al., 2019).

\section{Heritability}

It is a statistical tool used in breeding that gives us the degree of variation in phenotypic trait that is mainly due to genetic variation. High broad sense heritability was observed between $92.03 \%$ (plant spread) to $99.80 \%$ (days to maturity) (Masal, 2000). For traits like first flowering, days to $50 \%$ flowering, days to pod initiation, plant height, primary branches per plant and secondary branches per plant high heritability was observed (Dahiya et al., 2000). In 30 different genotypes of Pea (Pisum sativum L.) high heritability combined with high genetic advance for traits were recorded for plant height, pod yield per plant, seed yield per plant, no. of primary branches and 100 seed weight (Sureja and Sharma 2000). In 24 different genotypes of field Pea (Pisum sativum L.) high heritability coupled with high genetic advance for all traits were observed for seeds per pod, days to $50 \%$ flowering etc. (Mahanta et al., 2001). Within the characters, pod yield per plant, number of pods per plant, seed weight and pod weight, high heritability coupled with high genetic advance were recorded for thirty-one genotypes (Raffi et al., 2004). Among 31 different genotype of Pea (Pisum sativum L.) high broad sense heritability coupled with high genetic advance was recorded for all traits excluding days to flowering and pod length (Singh and Singh 2006). Maximum heritability coupled with high genetic advance for pods per plant and pod yield per plant was recorded in 20 genotypes of Pea (Pisum sativum L.) (Sharma et al., 2007). Among 40 different genotypes of Pea (Pisum sativum L.), high broad sense heritability coupled with high genetic advance for all traits except no. of greens per pod was observed (Singh et al., 2007). High heritability coupled with high genetic advance for green pod yield per plot, 100 seed weight and weight of pods per plant in 12 different germplasm of Pea (Pisum sativum L.) were recorded (Nawab et al., 2007). In traits pod width \& seed no. per plant, environmental effect on yield, fresh pod weight, pod length, pod number per plant and leaf area heritability was found to be much higher (Dursun, 2007). Very high heritability estimates for 100 seed weight, number of pods and seed yield (Singh et al., 2007). For traits first flower $(59 \%)$ followed by days to maturity (39\%) high heritability was recorded in thirteen genotypes (Msolla et al., 2008). Among 20 genotypes of Pea (Pisum sativum L.) moderate to high broad sense heritability coupled with high genetic advance for plant height, pod length and 100 seed weight was recorded indicating role of additive gene action in the expression of these traits (Singh et al., 2011). Heritability was high (60\%) for all traits except number of branches per plant and number of seeds per pod in seventy-five genotypes (Mudasir et al., 2012). High heritability for days to $50 \%$ flowering and plant height while low heritability coupled with high genetic advance for total soluble solids was recorded which indicate that heritability is basically due to additive gene effect (Sharma and Sharma 2013). High heritability $(>80 \%)$ for vine length, internodal length, number of nodules per plant, nodule fresh weight, tender pod fresh weight, 100 seeds weight and pod yield were recorded 
in sixty-five genotypes (Singh et al., 2014). High heritability for pods per plant $(88.20 \%)$ and lowest for branches per plant $(38.50 \%)$ was observed in thirty-three genotypes (Devi et al., 2014). Maximum heritability was observed in green pod yield per hectare (99.84\%) minimum heritability in pod weight $77.63 \%$ was observed in 40 genotypes (Savita et al., 2014). Maximum heritability in 100 seed weight $(99.50 \%) \&$ lowest heritability in green pod breadth $(26.80 \%)$ in twenty-four genotypes (Prakash et al., 2015). Among 54 different genotypes of Pea (Pisum sativum L.) high heritability coupled with high genetic advance for pod yield, no. of pods/plant and total phenols was recorded (Kumar et al., 2015). High genetic advance for traits: plant height, seeds per pot and 100 seed weight were recorded in 12 different genotypes of Pea (Pisum sativum L.). This shows that the particular traits can be used as effective selection during any breeding program for yield improvement (Jaberson et al., 2016). High heritability for green pod yield, basal internode diameter, days to 1 st green pod picking, plant height, basal internodal length, green pod width, no of pods per plant, days to $50 \%$ flowering, no of secondary branches per plant was estimated (Panda et al., 2016). Genotype named Varun was treated with different concentration of chemical mutagen i.e., gamma rays and observed maximum heritability for 100 -seed weight, plant height and length of pod (More et al., 2016). At two different locations the heritability varies from $38.9 \%$ for primary branch to $86.9 \%$ for harvest index at one location \& from $30.5 \%$ for days to emergence to $95.86 \%$ at another location for nine genotypes (Wondimu et al., 2017). Maximum heritability coupled with high genetic advance for pod yield, pod yield per plot and plant height was recorded which indicate presence of additive gene action (Gudadinni et al., 2017). Among two crosses i.e. IM 9214-10x Rachna (C-1) and IM 921410x Ambika (C-2) maximum heritability coupled with high genetic advance was recorded for clusters for plant, pod bearing length and seed yield per plant (Meena et al., 2017). High heritability coupled with genetic advance in 35 different genotypes of Pea (Pisum sativum L.) was recorded for plant height, days to $50 \%$ flowering \& pods/plant (Kumar et al., 2018). High heritability for protein content followed by number of root nodules per plant and lowest heritability was recorded for pod length $(\mathrm{cm})$ in thirty-six genotypes (Jhanavi et al., 2018). High heritability in no. of pods per plant (99.59) accompanied by green pod yield/plant $(99.43 \%)$ \& test weight (99.35\%) and lowest heritability for days to germinate $(82.94 \%)$ was recorded in forty genotypes (Singh et al., 2018). For traits pod width, pod weight, green pod yield high heritability was recorded and for trait days to first picking lowest heritability was recorded (Ramdeep et al., 2018). In 29 genotypes of Pea (Pisum sativum L.), high heritability coupled with high genetic advance were recorded for plant height, seed yield per plant, no. of pods/plant $\&$ no. of seeds/plant. Thus, these characters can be used in any breeding program for yield increasement (Pathak et al., 2019). Combination of high heritability \& high genetic advance in no. of pods per plant, pod length, pod yield/plot, 100 seed weight \& TSS was recorded in 20 varieties of Pea (Pisum sativum L.) (Kumar et al., 2019).

\section{Genetic advance}

Maximum genetic advance was recorded in 100 seed weight accompanied by green pod yield/plant (Nandi et al., 1995). Maximum genetic advance in pod yield/plant, plant height \& 100 seed weight were recorded (Masal, 2000). Very high genetic advance for pod yield/plant, no. of pods/plant, seed weight \& pod weight (Rai et al., 2000). High heritability for days to maturity and lowest heritability for number of seeds/plants was 
recorded (Raffi et al., 2004). For the traits, days to first flowering, days to $50 \%$ flowering, days to pod initiation, plant height, primary branches per plant and secondary branches per plant maximum genetic advance was observed (Dahiya et al., 2006). Highest genetic advance was recorded for 100 seed weight, number of pods/plant \& seed yield (Singh et al., 2007). Maximum genetic advance was recorded for traits like 100 seed weight, seed yield/plant in 42 different genotypes (Singh et al., 2013). Genetic advance in terms of percentage of mean was maximum for number of pods/plant $(58.00 \%)$ \& minimum for days to $50 \%$ maturity $(14.95 \%)$ in forty genotypes (Savita et al., 2014). Maximum genetic advance for 100seed weight was recorded in forty-five genotypes (Kumar et al., 2014). For traits plant height and days to $50 \%$ flowering maximum genetic advance was recorded (Lad et al., 2017). Maximum genetic advance for plant height and seed yield per plant in seventy-five genotypes was recorded (Panchbhaiya et al., 2017). At two different locations the percentage of genetic advance varied from $6.8 \%$ (Days to maturity) to $65.47 \%$ (stand out at harvest) in nine different genotypes (Wondimu et al., 2017). Highest genetic advance were recorded for yield/plant $(72.78 \%) \&$ pod flesh thickness $(0.11 \%)$ in seventy-five genotypes (Jhanavi et al., 2018).

\section{Correlation}

It is a statistical measure that indicates the extent to which two or more variables fluctuate together. Maximum GCV \& PCV in days to flowering, days to $50 \%$ flowering, days to pod initiation, plant height, primary branches /plant \& cluster /plant were estimated (Dahiya et al., 2000). In seed yield /plant positive correlation was found with days to first flower, days to maturity, plant height, plant spread, no. of branches /plant, no. of pods /branch and no. of seeds /pod breadth while non-significant negative correlation within pod breadth, pod length \& 100 seed weight at phenotypic \& genotypic level (Shinde et al., 2001). Highest GCV and PCV for 20 seed weight $(42.19 \%$ and $42.29 \%)$, seed yield /plant $(39.35 \%$ \& $47.64 \%$ ) and number of seeds per plant (31.43\% and $40.60 \%)$ and moderate GCV and PCV were recorded for number of pods per plant (19.81\% and 26.75\%), pod length (17.10\% and $19.12 \%)$, plant height $(15.67 \%$ and $17.63 \%$ ) and lowest GCV and PCV were recorded for days to maturity $(7.19 \%$ and $8.15 \%)$ and days to $50 \%$ flowering $(6.99 \%$ and 8.01) respectively (Raffi et al., 2004). Positive and significant correlation with green pod yield was recorded for no. of green pods per plant, no. of grains per pod; shelling percentage and pod length (Mehta et al., 2005). Significant positive correlation of green yield plant with plant height, pod length and seeds per pod and non-significant negative correlation with days to flowering was recorded and GCV was higher than PCV (Singh and Singh 2005). In 18 different genotypes of Pea (Pisum sativum L.) it was recorded that at genotypic and phenotypic level seed yield possess significant positive correlation with no. of seeds per pod, pod length and pod diameter and significant negative correlation of no. of days to $50 \%$ flowering with no. of pods per plant and no. of branches per plant (Singh and Yadav (2005). At phenotypic level days to flowering with days to maturity, plant height with no. of pods per plant, pod length with plant height are positively correlated with each other (Sirohi et al., (2006). Pod yield /plant contributed positive correlation with the pod length, pod weight and seed weight in genotypic and phenotypic levels (Rai et al., 2006). Positive and significant correlation between correlation no. of seeds /pod, no. of pods /plant \& pod length with grain yield was observed in different genotypes (Salehi et al., 2008). Correlation within pod no. /plant \& 
yield, fresh pod weight \& yield, seed number /pod \& yield were found significantly positive (Dursun, 2007). In 12 different types of Pea (Pisum sativum L.) it was recorded that at genotypic and phenotypic level green pod yield per plot have significantly positive correlation with no. of seeds per pod and pod weight per plant. This indicates that these characters could be considered as a major green pod yield contributing characters in garden Pea (Nawab et al., 2008). In 10 different indigenous and exotic germplasm of Pea (Pisum sativum L.) it was observed that traits like no. of flowers, no. of pods and no. of seeds per pod have strong positive correlation with yield (Guleria et al., 2009). Significant correlation of seed yield per plant was recorded for plant height, biological yield, harvest index, no. of pods per plant and days to maturity (Lavanya et al., 2010). Significantly positive correlation with seed yield /plant was recorded with no. of branches per plant, no. of pods per plant, pod length, no. of seeds per pod \& 100-seed weight at GCV \& PCV level and significantly negative correlation in days to $50 \%$ flowering \& days to maturity was observed and GCV was higher as compared to PCV (Mudasir et al., 2012). Low level of differences was observed within PCV and GCV for days to 50\% flowering, plant height, 100 seed weight \& seed yield in fifty-seven genotypes (Ahmed $e t$ al., 2013). High GCV and PCV for length of inflorescence $(52.94 \%$ \& $51.17 \%)$, no. of pods /plant $(43.22 \%$ \& $42.25 \%) \&$ marketable pod yield /plant $(42.81 \%$ \& $41.71 \%) \&$ moderate GCV \& PCV were recorded for no. of inflorescence /plant (35.04\% \& 34.16\%), number of flowers per inflorescence $(33.85 \%$ and $30.64 \%)$ and pod weight $(31.15 \%$ and $30.71 \%$ ) and lowest GCV and PCV were recorded for days to last pod harvest $(9.33 \%$ and $8.98 \%$ ) respectively in forty four genotypes (Kumar et al., 2014). Positively significant correlation of pod yield with days to flowering, average pod weight, branches per plant, pods per plant and plant height were recorded in seventeen genotypes (Devi et al., 2014). Marketable pod yield per plant was found significantly positively correlated at GCV \& PCV levels within length of inflorescence, no. of pods /inflorescence, no. of flowers /inflorescence and no. of inflorescences /plant in forty-five genotypes (Kumar et al., 2014). High genotypic coefficient variation \& phenotypic coefficient variation for traits 100-seed weight, plant height, green pod yield /plot, green pod yield /plant and green pod yield ( $\mathrm{q} / \mathrm{ha}$ ) in twentyfive genotypes (Prakash et al., 2015). In 28 different genotypes of Pea (Pisum sativum L.) it was recorded that seed weight per plant have significant positive correlation with no. of pods per plant, weight of pods per plant and harvest index (Tofiq et al., 2015). In 5 germplasm of forage Pea (Pisum sativum L.) it was concluded that seed yield posses positive significant correlation with pod stem and 1000 seed weight (Georgieva et al., 2016). There was a positive significant correlation of pod yield with pod length, pod width and no. of grains per pod in 15 different genotypes of Pea (Pisum sativum L.) (Thakur et al., 2016). For traits like no. of seeds /plant $(70.93 \%$ \& $73.83 \%)$, plant height $(52.16 \%$ and $59.13 \%)$ and no. of pods $(50.09 \%$ \& $51.99 \%$ ) highest GCV and PCV were recorded in forty-two genotypes (Topwal et al., 2016). Highly significant \& positive association with germination percentage, plant height, no. of primary branches /plant, number of secondary branches /plant, no. of clusters /plant, no. of pods /cluster, no. of pods per plant, pod length, pod circumference, harvest index both at genotypic and phenotypic level in twelve genotypes (Heena et al., 2016). High GCV and PCV in plant height, seed yield /plant, pod yield /plant, pod yield /hectare, no. of pods /cluster, no. of pods /plant \& 100 seed weight in seventy-four genotypes (Panchbhaiya et al., 2017). At genotypic 
level, seed yield per plant have significant positive correlation with protein was recorded in 29 different genotypes of Pea (Pisum sativum L.) (Toppo et al., 2017). Highest GCV and PCV were recorded for seed weight /pod $(145.12 \%$ \& $144.87 \%$, respectively (Lyngdoh et al., 2017). Significantly positive GCV were recorded in green pod yield with no. of pod /plant, single green pod weight, pod dry weight, pod length \& leaf area /plant and significantly negative GCV were recorded in green pod yield \& days to $50 \%$ flowering \& days to first picking in thirty four genotypes (Alemu et al., 2017). Highest GCV and PCV was recorded for plant height $(41.30 \%$ and $42.16 \%)$ and lowest GCV and PCV for pod length $(9.21 \%$ and 11.87$)$ respectively (Lad et al., 2017). Significantly positive correlation at PCV and GCV levels in seed yield /plant with no. of pods /plant, pod length, no. of seeds /pod \& 100 seed weight and significantly negative correlation within days to $50 \%$ flowering \& days to maturity were recorded in thirteen genotypes (Razvi et al., 2017). Among 120 different genotypes of Pea (Pisum sativum L.), positive correlation of seed yield per plant with plant height, no. of seeds per pod, no. of primary branches per plant, no. of pods per plant and 100 seed weight was observed (Kumar et al., 2017). In 40 indigenous and 10 exotic germplasm of Pea (Pisum sativum L.) it was recorded that there was a positive significant relation of seed yield per plant with biological yield per plant, plant height, no. of pods per plant and 100 seed weight and negative correlation with days to maturity (Singh et al., 2017). Genotypic and phenotypic coefficient of variability was recorded in the plant height, no. of primary branches, pod length, pod width, pod flesh thickness, no. of pods /cluster, no. of pods /plant, weight of ten pods, no. of root nodules /plant \& dry matter contents of pods \& roots in seventy four genotypes (Jhanavi et al., 2018). At genotypic and phenotypic level, pod yield/ha is positively correlated with primary branches/plant, cluster /plant, pods /cluster, pods /plant, yield /plant, root nodule and dry matter content in pod \& negative correlation was observed for days to flowering \& $50 \%$ flowering in twelve genotypes (Muthal et al., 2018). In 113 diverse germplasm of Pea (Pisum sativum L.), positive correlation of seed yield/plant with 100 seed weight, no. of pods/plant, harvest index and biological yield was recorded (Srivastava et al., 2018). Positive significant correlation of harvest index, seeds/pod, pod length \& 100 seed weight with seed yield/plant was observed in 120 genotypes of field Pea (Pisum sativum var. arvense) (Lal et al., 2018).

\section{Path coefficient analysis}

It indicates the fact that which character has most positive direct effect on yield. It has been reported that no. of pods /plant has a direct positive effect on yield per plant, pod width has high positive direct and pod length has negative direct effect on yield /plant (Nandi et al., 1997). It has been observed that no. of primary branches, is the only trait that influence pod yield (Mohamad., 1996). It has been reported that pod yield/plant exhibit direct effect on no. of grains/pod, pod length and 1000 seed weight (Choudhary and Sharma 2003). At genotypic level, it was recorded that seeds/pod possess direct effect with seed yield (Sirohi et al., 2006). Among 31 germplasm of Pea (Pisum sativum L.) it was recorded that seed yield/plant exhibit positive direct effect with plant height and grains/pod (Singh and Singh 2006). In 20 different genotypes of Pea (Pisum sativum L.) it was concluded that pod/plant, plant height $\&$ pod length have positive direct effect with green pod yield (Sharma et al., 2007). Path coefficient analysis in 33 diverse germplasm of Pea (Pisum sativum L.) concluded that 100 seed weight \& primary branches are important element of yield which can be used 
in selection of improvement in germplasm (Sardana et al., 2007). Among 20 diverse germplasm of Pea (Pisum sativum L.) it was recorded that green pod yield/plant possess positive direct effect on 100 seed weight, no. of pods/plant, no. of seeds/pod \& days to $50 \%$ flowering (Nawab et al., 2008). Among 30 diverse genotypes of Pea (Pisum sativum L.) it was concluded that in every environmental condition no. of pods per plant possess a positive direct effect with pod yield per plant (Dhama et al., 2010). At genotypic level green pod yield possess positive direct effect on no. of pods per plant, 100 pod weight (Sharma and Sharma (2012). Path coefficient analysis at genotypic level revealed that seed yield has positive direct effect on harvest index and biomass yield (Million 2012). Among 26 diverse germplasm of Pea (Pisum sativum L.) it was recorded that seed yield/plant possess positive direct effect days to $50 \%$ flowering, days to $50 \%$ harvesting, no. of branches/plant, pods/plant \& 100 seed weight (Siddika et al., 2013). Among 42 different genotypes days to first picking, 100 seed weight, pod length \& seed yield/plant contributed positively towards pod yield/ha (Singh et al., 2013). It has been observed that at phenotypic level green pod yield /plant, has the maximum direct effect on pod yield/hectare in 40 different types of French bean (Phaseolus vulgaris L.) (Savita et al., 2014). Among 7 diverse germplasm of Pea (Pisum sativum L.), there is a positive direct relation of seed weight/plant with biological weight/plant $\&$ harvest index whereas positive indirect relation with no. of pods/plant (Tofiq et al., 2015). Path coefficient analysis for seed yield and various components revealed that protein content has very less direct positive effect on seed yield (Toppo et al., 2017). In 120 different genotypes of Pea (Pisum sativum L.), positive direct effect of seed yield/plant with days to maturity \& 100 seed weight was observed (Singh et al., 2017). Among 113 genotypes of Pea (Pisum sativum
L.) path coefficient analysis revealed that seed yield per plant possess the positive direct effect on harvest index, biological yield, 100 seed weight and no. of pods per plant (Srivastava et al., 2018). Among 35 different germplasm of Pea (Pisum sativum L.) it was recorded that green pod yield/plant exhibit positive direct effect on plant height and pod length but internodal length exhibit negative direct effect on green pod yield/plant (Vijaya Kumar et al., 2019)

\section{Genetic divergence}

Genetic divergence is usually referring to that population having same ancestors and these populations accumulate independent genetic changes after sometimes. In 62 different genotypes of French beans (Phaseolus vulgaris L.) grouped into 11 clusters and observed that no. green pod /plant, 100 seed weight, plant height $\&$ reproductive branches contributed towards total divergence (Govamakoppa et al., 2002). Among 100 different germplasm of Pea (Pisum sativum L.) when classified into 8 clusters. Cluster 1 possess highest genotype accompanied by cluster 2. Highest intra-cluster distance is of cluster 8 and highest inter cluster distance is of cluster 5 and 7 (Kumar et al., 2006). From 20 Characters, total divergence is contributed by no. of pods per plant followed by no. of racemes/plant \& 100 seed weight, contributed least $(0.19 \%)$ (Hossain et al., 2013). It has been revealed that 100 seed weight has the most no. of contribution (38.33\%) towards total divergence accompanied by pod weight $(17.02 \%)$ and protein content $(11.52 \%)$ in forty-four genotypes (Kumar et al., 2014). Among 66 different germplasm of French bean (Phaseolus vulgaris L.), the maximum genetic divergence was reported for days to $50 \%$ flowering accompanied by 1000 seed weight, green pod yield, pd weight and pod length (Gangadhara et al., 2014). When 34 germplasm of French bean (Phaseolus 
vulgaris L.), grouped into 5 clusters and observed that vitamin $\mathrm{C}$ content, no. of pods/plant \& dry matter content has maximum contribution in total divergence (Verma et al., 2014). Among 20 germplasm of Pea (Pisum sativum L.) when grouped in 4 clusters, cluster 3 possess largest no. of genotype accompanied by cluster 2 . Cluster $2^{\text {nd }}$ possess highest intra-cluster distances whereas cluster $3^{\text {rd }}$ and $1^{\text {st }}$ possess highest inter-cluster distance (Gupta et al., 2017). Among different genotypes of Pea (Pisum sativum L.) cluster $5^{\text {th }}$ possess maximum mean values for root length, no. of pods/plant and days to $50 \%$ flowering. Maximum value of inter-cluster distance was exhibited by cluster 5 followed by cluster 2 and cluster 1 (Bijalwan et al., 2018).

\section{References}

Alemu, Y., Alamirew, S., Dessalegn, L. 2017. Correlation and path Analysis of Green Pod Yield and its components in Snap bean (Phaseolus vulgaris L.) Genotypes. International Journal of Research in Agriculture and Forestry, Volume 4, PP 30-36.

Biswas, M.S., Hassan, J. and Hossain, M.M. 2010. Assessment of genetic diversity in French bean (Phaseolus vulgaris L.) based on RAPD marker. African Journal of Biotechnology. Vol.9(32).

Bhaganna, H., Salimath, P.M., Nagarajappa, A., Asha, I.S. and Gangaprasad, S. (2015). Study on genetic variability, correlation and path analysis with green pod yield and yield attributing traits in French bean (Phaseolus vulgaris L.). The ecoscan. 7 (special issue): 41-46.

Chaubey, B.K., Yadav, C.B., Kumar, K. AND Srivastava, R.K. 2012. Genetic variability, character association and path coefficient analysis in faba bean. Journal of Food Legumes. 25(4): 348350.

Chaudhary, D.K. and Sharma, R.R. (2003). Genetic variability, correlation and path analysis for green pod yield and its componentsin garden pea. Indian $J$. Hort., 60: 251-256.

Dahiya, A., Sharma, S.K., Singh, K.P. and Kumar, A. 2000. Variability studies in French bean (Phaseolus vulgaris L.), Annals of Biology. 16(2): 201-204.

Devi, J., Sharma, A., Singh, y., Katoch, V., Sharma, K.C. 2015. Genetic Variability and character association studies in French bean (Phaseolus vulgaris L.) under North-Western Himalayas. Legume Research, 38 (2): 149-156

Dhiman, K.R. 1996. Path analysis in dry beans germplasm. Indian Journal of Genetics and Plant Breeding. 56(4): 439-441.

Dursun, A. 2007. Variability, Heritability and Correlation studies in bean (Phaseolus vulgaris L.) genotypes. World J. Agric. Sci. 3 (1): 12-16.

Gudadinni, P., Bahadur, V., Ligade, P., Topno, S. E. and Prasad, V. M., (2017). Study on genetic variability, heritability and genetic advance in garden pea (Pisum sativum var. hortense L.).International Journal of Current Microbiology and Applied Sciences., 6(8): 2384-2391.

Guleria, S., Chongtham, N., Dua, S. (2009). Genetic variability, correlation and path analysis studies in pea (Pisum sativum L.). CropResearch (Hisar). 38:179-183.

Gupta, A., Singh, M.K., Kumar, M., Singh, S.K., Katiyar, H. and Kumar, V. (2017). Study of Genetic Divergence in Pea (Pisum sativum L.) based on AgroMorphic Traits. Int.J.Curr.Microbiol. App.Sci. 6(11): 3816-382.

Heena, M.S., Devaraju and Ravi, C.S. 2016. Correlation and path analysis for yield and yield related traits in French bean (Phaseolus vulgaris L.) in Karnataka. Green Farming Vol 7(4): 815-818.

Hossain, M.K., Alam, N., Teixeira da Silva, J.A., Biswas, B.K., Mohsin, G.M. 2013. Genetic Relationship and Diversity based on Agro- Morphogenic Characters in yard long bean (vigna sesquipedalis L. Fruw.) Germplasm. International Journal of Plant Breeding, 7 (2), 129- 
135.

Jhanavi, D.R., Patil, H.B., Justin, P., Revanappa, H.P., Mulla, S.W.R. and Sarvamangla, C. 2018. Genetic variability, heritability and genetic advance studies in French bean (Phaseolus vulgaris L.) genotypes, Indian J. Agric. Res., 52(2): 162-166.

Jyoti, D., Sharma, A., Singh, Y., Katoch, V. and Sharma, K.C. 2015. Genetic variability and character association studies in French bean (Phaseolus vulgaris L.) under North-Western Himalayas. Legume Research, 38(2): 149-156.

Junaif, N., Wani, K.P., Khan, S.H., Jabeen, N., Mushtaq, F. and Ummiyah, H.M. 2010. Genetic variability in dwarf French bean (Phaseolus vulgaris L.). Asian J. Hort. 5(1): 117-118.

Kamaluddin, A.S. 2011. Variability, correlation and path analysis for seed yield and yield related traits in common beans (Phaseolus vulgaris L.) Indian Journal of Horticulture. 68(1): 61-65.

Kumar, K., Prasad, K.D. and Verma A.K. 2003. Genetic variability, correlation and path coefficient analysis in greengram. $J$. Agric. Res. Birsa Agric. Univ. 15 (1): 97-101.

Kumar, P.A., Reddy, R.V.S.K., Pandravada, S.R., Rani, C. H.V.D. Chaitanya, V. 2014. Genetic variability, Heritability and genetic advance in pole type French bean (Phaseolus vulgaris L.), Plant Archives Vol. 14 No. 1, pp.569-573.

Kumar, B. (2008). Studies on Variability, heritability and genetic advance in pea (Pisumsativum L.). International Journal of Plant Sciences, 3(1): 211212.

Kumar, M., Jeberson, M.S., Singh, N.B. and Sharma, R. (2017). Genetic analysis of seed yield and its contributing traits and pattern their inheritance in Field pea (Pisum sativum L.). International Journal of Current Microbiology and Applied Sciences. 6(6):172-181.

Kumar, R., Kumar, M., Dogra, R. K. and Bharat, N. K., (2015). Variability and character association studies in garden pea (Pisum sativum var. hortense L.) during winter season at mid hills of Himachal Pradesh. Legume Research. 38(2): 164-168.

Lal, K., Kumar, R., Shrivastava, S.P., Kumar, A. and Singh, Y.(2018). Genetic Variability, Character Association and Path Analysis of Seed Yield andIts Contributing Traits in Field pea (Pisum sativum L. var. arvense). Int. J. Curr. Microbiol. App. Sci. 7(06): 1815-1820.

Lavanya, G.R., Singh, D., Vinoth, R. (2010). Genetic variability, character association component analysis infield pea (Pisum sativum L. var. arvense) Madras Agric J. 97(10/12):329-331.

Lad, D.B., Longmei, N., Borle U.M. 2017. Studies on Genetic Variability, association of characters and path analysis in French bean (Phaseolus vulgaris L.). International Journal of Pure Applied Bioscience, 5(6): 10651069.

Lyngdoh, Y.A., Thapa, U., Shadap, A., Singh, J., and Tomar, B.S. 2017. Studies on genetic variability and character association for yield and yield related traits in French bean (Phaseolus vulgaris L.), Legume Research, 41(6): 810-815.

Masal, V.V. 2000. Genetic diversity and path analysis in French bean (Phaseolus vulgaris L.). Crop Science, 2(3): 49-55.

Mishra, S., Kumar, M. and Sahu, G.S. 2008. Relationships among yield contributing characters in pole type French bean (Phaseolus vulgaris L.). Orrisa J. Hort. 36(2): 108-113.

More, A.D. and Borkar A.T. 2014. Analysis of Genetic Variability, Heritability, Genetic advance in (Phaseolus vulgaris L.), Int. J. Curr. Microbiol. App. Sci, 5(10): 494-503.

Msolla, S.N. and Mduruma, Z.O. 2007. Estimate of Heritability for maturity characteristics of an early $x$ late Common bean (Phaseolus vulgaris L.) cross (TMO 216 X CIAT 16-1) and 
Relationships among maturity traits with Yield and Components of Yield. Tanzania, J. Agric.Sc. Vol.8 No. 1, 1118.

Mukesh, T. and Geeta, G. 2016. Studies on genetic variability in different genotypes of French bean (Phaseolus vulgaris L.). International Journal of Life Science Scientific Research, 2(3): 219-221.

Muthal, K.M., Patil, H.B., Ganiger, V.M., Ajjappalvar, P.S., Pallavi, H.M. 2018. Correlation and Performance evaluation of French bean (Phaseolus vulgaris L.) varieties. International Journal of Chemical Studies, 6(4): 2436-2439.

Mudasir, S., Sofi, P.A., Khan, M.N., Sofi, N.R., Dar, Z.A. 2012. Genetic Diversity, Variability and character association in local common bean (Phaseolus vulgaris L.) Germplasm of Kashmir. Electronic Journal of Plant Breeding, 3(3): 883891.

Mahanta, I.C., Senapati, N., Samal,K. and Dhal, A. (2001). Genetic variability performance,character association and coheritability in field pea (Pisum sativum L.). Indian J. Agric. Sci., 24:9296.

Meena, B.L., Das, S.P., Meena, S.K., Kumari, R., Devi, A.G. and Devi, H.L. (2017). Assessment of GCV, PCV, Heritability and Genetic Advance for Yield and its Components in FieldPea (Pisum sativum L.). Int. J. Curr. Microbiol. App. Sci. 6(5): 1025-1033.

Mehta, S., Kohli, V.K., Mehta, D. and Kumar, D. (2005). Genetic variability studies in pea (Pisum sativum L.).Haryana $J$. Hort. sci. 34(112):140-141.

Nawab, N. N., Subhani, G. M., Qamar, K. M. and Saeed, S. A. (2008). Genetic variability, correlation and path analysis studies in garden pea (Pisum sativum L.). Journal of Agricultural Research. 46(4): 333-340.

Nath, S. and Korla, B.N. 2004. Path analysis of some quantitative characters in dwarf French bean (Phaseolus vulgaris L.) in relation to pod yield. Legume Research,
27(3): 228-230.

Panchbhaiya, A., Singh, D.K., Jatav, V., Mallesh, S. and Verma, P. 2017. Studies on variability, heritability and genetic advance for yield and yield contributing characters in French bean (Phaseolus vulgaris L.) germplasm under tarai region of Uttarakhand, Journal of Applied and Natural Science, 9(4): 1926-1930.

Pathak, V.N., Pandey, R.K., Verma, S.P, Ray, J., Singh, V. and Jee, C. (2019). Studies of geneticvariability, heritability and genetic advance for yield contributing traits in fieldpea (Pisum sativum L.). Journal of Pharmacognosy and Phytochemistry. 8(4): 2587-2589.

Panda, A., Paul, A., Mohapatra, P. 2016. A Study on Variability, character association and path analysis for Pod Yield in French bean (Phaseolus vulgaris L.) International Journal of Bio-resource and Stress Management, 7(1): 033-039.

Pandey, V., Singh, V.K. and Upadhyay, D.K. (2013). Determination of green pod yield components in French bean (Phaseolus vulgaris L.) through correlation and path coefficient analysis. Vegetos, 26(2): 438-443.

Patil, A.R., Bendale, V.W., Bhave, S.G. and Mehta, J.L. 2004. Correlation and path analysis studies of biomass partitioning characters in cowpea (Vigna unguiculata L.). Orrisa J. Hort., 32(1): 19-21.

Prakash, J., Ram, R.B., Meena, M.N. 2015. Genetic variation and characters interrelationship studies for quantitative and qualitative traits in French bean (Phaseolus vulgaris L.) under Lucknow conditions. Legume Research, 38 (4): 425-433.

Rai, N., Asati, B.S., Singh, A.K., Yadav, D.S. 2006. Genetic variability character association and path coefficient study in pole type French bean (Phaseolus vulgaris L.), Indian Journal of Horticulture, 63(2): 188-191. 
Rachman, E.S., Syukur, M., Marwiyah, S. 2018. Estimation of genetic parameters on $\mathrm{F} 3$ French bean (Phaseolus vulgaris L.) population. IOP Conf. Series: Earth and Environmental Science, 196012006.

Raffi, S.A. and Nath, U.K. 2004. Variability, Heritability, Genetic advance and Relationships of Yield and Yield Contributing Characters in Dry Bean (Phaseolus vulgaris L.), Journal of Biological Sciences, 4(2): 157-159.

Ramandeep., Dhillon, T.S., Dhall, R.K., Gill, B.S. 2018. Genetic Variability of Yield and Yield attributing traits in French bean (Phaseolus vulgaris L.). Agric. Res. J. 55 (2):219-223.

Razvi, S.M., Khan, M.N., Bhat, M.A., Ahmad, M., Ganaie, S.A., Sheikh, F.A., Najeeb, S., Parry, F.A. 2017. Morphological Variability and Phylogenetic analysis in common bean (Phaseolus vulgaris L.) Legume Research DOI: 10.18805/LR3421 .

Savita., Singh, D.K., Singh, J.P. 2014. Heritability, genetic advance and path analysis for pod yield and yield related traits in French bean. International Journal of basic and applied agricultural research. Vol.12 no.3 pp.398-402.

Shaban, N. (2005). Analysis of the correlation and regression coefficients of the interaction between yield and some parameters of snap bean plants. Journal Science. 3(6): 27-31.

Singh. A. and Singh, D.K. 2013. Genetic variability and character association analysis in French bean (Phaseolus vulgaris L.) Indian Journal of Agricultural Sciences; 84(8): 925-930.

Singh, A.K. 2003. Variability and Correlation studies for certain Metric traits in French bean (Phaseolus vulgaris L.). The Hort. J., 16(2): 99-101.

Singh, D.K., Singh, D.P., Singh, S.S. 2018. Studies of genetic variability and genetic advance for yield and related traits in French bean (Phaseolus vulgaris L.). Journal of Pharmacognosy and
Phytochemistry; 7(2): 236-240.

Sirohi, A. (2005). Analysis of the correlation and regression coefficients of the interaction between yield and some parameters of snap bean (Phaseolus vulgaris L.) plants. J. Sci. 3(6): 27-31.

Swarup, V. (2012). Vegetable Science and Technology in India. Kalyani Publishers, New Delhi. pp 480.

Sharma, A., Sood, M., Rana, A. and Singh, Y. (2007). Genetic variability and association studies for garden pod yield and component of horticultural traits in garden pea (Pisum sativum L.) under high dry temperate conditions. India. $J$ Hort. 64:410-414.

Sharma, B.B. and Sharma, V.K. (2012). Character association and path analysis studies for yield in horticultural traits in garden pea. Envt. And Eco. 30(4A):1591-1598.

Singh, J.D. and Singh, I.P. (2006). Genetic variability, heritability, expected genetic advance and character association in field pea (Pisum sativum L.). Legume Res., 29:65-67.

Sirohi, S.P.S., Yadav, R. and Malik, S. (2006). Genetic variability, Correlation and path analysis for seed yieldand its component characters in pea (Pisum sativum L.) Plant Archives. 6(92):737-740.

Sureja, K.P. and Sharma, A.K. (2000). Genetic variability, Correlation and path analysis garden pea (Pisum sativum L.). Current Research. 9(1):43-45

Thakur, S., Thakur, R. and Mehta, K, D. (2016). Genetic variability and association studies for green pod yield and component horticultural traits in garden pea under high hill dry temperate conditions of Tabo valley of Spiti district of Himachal Pradesh. International Journal of Science, Environment and Technology. 5(4):1987-1992.

Thamburaj, S. and Singh, N. (2015). Text book of vegetables, tuber crops and spices. ICAR, New Delhi. pp.196-200.

Tofiq, S. E., Khaleq, D. A., Amin, T. N. H. and 
Azez, O. K. (2015). Correlation and path coefficient analysis in seven field pea (Pisum sativum L.). International Journal of Plant, Animal and Environment Sciences, 5(4): 2231-4490.

Topo, H., Sharma, R.N and Thakur, A. (2017). Path analysis for quality traits in field pea (Pisum sativum L.). Agric. Sci.Dig., 37 (4): 324-326.

Topwal, M., Gaur, G. 2016. Studies on Genetic Variability in different Genotypes of French bean (Phaseolus vulgaris L.). Int. J. Sci. Scientific Research, 2(3):219221

Urbano, G.P., Arnda and Gomez, E.V. (2003). Nutrition evolution of pea (Pisum sativum L.) protein diets after, mild hydro thermal treatment and with and without added phytase, J.Agric. Food Chem., 51 (8): 2415-2420

Vijaya Kumar, T. N., Alloli, T. B., Hadimani,
H. P., Ajjappalavar, P. S., Satish, D. Kareem, A. and Hanchinamani, C. N. (2019). Studies on Genetic Variability, Heritability and Genetic Advance in Garden Pea (Pisum sativum L.) varieties. Int. J. Curr. Microbiol. App. Sci. 8(12):3032-3038.

Venkatesan, M., Prakash, M. and Ganesan, J. (2003). Correlation and path analysis in cow pea (Vigna unguiculata L.). Legume Research, 26(2): 105-108.

Wondimu, W. and Bogale, A. 2017. Genetic Variability, Heritability, Genetic advance of some Haricot bean (Phaseolus vulgaris L.) varieties at Bench-Maji Zone, Southwest Ethiopia. Asian Journal of Crop Science DOI: 10.3923/acjs.2017.133.140.

\section{How to cite this article:}

Akshita Bisht and Savita. 2020. Character Association in French Bean (Phaseolus vulgaris L.) and Pea (Pisum sativum L.) A Review. Int.J.Curr.Microbiol.App.Sci. 9(11): 798-811. doi: https://doi.org/10.20546/ijcmas.2020.911.097 